\title{
41 Cooper Union Square - architektura bezpieczna, architektura generatywna
}

\author{
Sławomir Wojtkiewicz \\ e-mail: s.wojtkiewicz@pb.edu.pl
}

Politechnika Białostocka, Wydział Budownictwa i Inżynierii Środowiska, ul. Wiejska 45A, 15-351 Biatystok

Referat zrealizowany w ramach prac statutowych: S/WBilś/2/2016 finansowany z środków MNiSW

\begin{abstract}
Streszczenie: Jednym z kryteriów projektowania architektury metodami generatywnymi jest wielokryteriowość, uwzględniająca wszystkie składowe procesu projektowania. Istotnym jej czynnikiem branym pod uwagę jest także bezpieczeństwo i przyjazne człowiekowi środowisko przestrzeni. Systemy generatywne są zaawansowanym językiem kształtowania geometrii bryły budynku, jej funkcji oraz zrównoważonym systemem dochodzenia do rozwiązań przestrzennych, w których człowiek traktowany jest priorytetowo. Budynek Cooper Union zaprojektowany przez grupę Morphosis, znajdujący się w Nowym Jorku jest wybitnym przykładem osiągania interesującej formy przestrzennej oraz układu funkcjonalnego, którego zakres formalny podyktowany jest zapewnieniem bezpiecznego środowiska oraz mikroklimatu pozwalającego także sensorycznie odbierać przestrzeń i architekturę. Zastosowane procedury generatywne na etapie projektowania pozwoliły w dużej mierze kształtować przestrzeń dostępną, ale i w wielu wypadkach wspomagającą kondycję fizyczną człowieka.

Artykuł przedstawia naukowe podstawy teorii generatywnych zastosowanych w projekcie The Cooper Union Building pod kątem zrównoważonego środowiska przestrzeni oraz architektury inteligentnej nie tylko w sensie estetycznym i funkcjonalnym, ale i technologicznym odnoszącym się wprost do postaw zdrowotnych człowieka - odbiorcy zaprojektowanej przestrzeni.
\end{abstract}

Słowa kluczowe: architektura generatywna, architektura

\section{Wprowadzenie}

Istnienie architektury generatywnej związane jest z kreacją możliwie zoptymalizowanej, zrównoważonej przestrzeni funkcjonalnej, technologicznej i po wtóre architektonicznej. Oznacza to naukowe i pragmatyczne podejście do procesu projektowania, który w początkowej fazie prac wyklucza działania subiektywne, koncentrując się na obiektywnych procedurach postępowania. Określony cel projektu staje się priorytetem w eksploracji maksymalnie wielu rozwiązań, badanych i porównywanych ze sobą poprzez sieć parametrów, relacji, ograniczeń. W ten sposób możliwe jest generowanie propozycji rozwiązania będącego wynikiem poszczególnych poziomów projektu, hierarchii ich ważności minimalizując w dużej mierze działania intuicyjne w decyzjach projektowych. Ten kierunek kreowania architektury szczególnie popularny w krajach zachodnich upodobnia proces projektowania do nauk informatycznych i poniekąd z tych dziedzin także wychodzi. Efektem jest jednak bardzo zrównoważona architektura o wybitnych wartościach architektonicznych przestrzeni. Priorytetowe cele ekologiczne, a także silne odniesienie do użytkownika jest zwrotem, który mocno identyfikuje proces projektowania z pojęciami interdyscyplinarnymi. Osiągana tymi środkami architektura wchodzi w kanon współczesnych realizacji ikonicznych, nie poprzez rozwiązania formy, ale przede wszystkim poprzez osiąganie jej środkami wielokryteriowej analizy. Ta wielokryteriowość decyduje o trwałości architektury nie samą architekturą, ale sposobami projektowania, a przede wszystkim określaniu rodzaju DNA budynku, rodzaju genetycznego uwarunkowywania formy, funkcji, technologii obiektu.

Jednym z przykładów architektury generatywnej jest znajdujący się w Nowym Jorku budynek The Cooper Union. Obecnie stanowi ikonę i dominantę ulicy 41 na Manhattanie. Fenomen jego istnienia, kompozycyjnej dominacji w przestrzeni, ale i przede wszystkim dostępności przestrzeni jest narzeczem niniejszego artykułu. 
Zagadnienie projektowania generatywnego jest dzisiaj faktem, a jednocześnie polem dociekań naukowych. Analiza niniejszego obiektu, także pod kątem jego interakcji z użytkownikiem, pod kątem bezpieczeństwa i dostępności jest niewielkim odniesieniem do niezwykle ciekawego zjawisk w teorii architektury jakim są kierunki procedur projektowych generatywnych. Oddźwięk architektury generatywnej w przestrzeni jest coraz silniejszy, a jego istnienie ma zwłaszcza kluczowe znaczenie w architekturze "strategicznej”, takiej jak szkoły, szpitale, lotniska, dworce, urzędy, muzea, teatry, galerie, zespoły mieszkaniowe, itp.

\section{Cel pracy}

Celem pracy jest ocena aspektów generatywnych w projektowaniu architektury bezpiecznej, dostępnej, zrównoważonej, ikonicznej. W pracy omówione zostaną składniki języka projektowania generatywnego, a sam sposób powstawania przestrzeni architektonicznej opisany zostanie w postaci procedur oraz procesów bliskich działaniom natury w kreowaniu form życia. Za cel postawiono opisanie mechanizmów projektowania generatywnego. Tym samym wyłonienia ich korzyści w osiąganiu wielokryteriowej i interdyscyplinarnej przestrzeni zintegrowanej funkcją, technologią, dostępnością, bezpieczeństwem, ekologią, psychologią. To właśnie takimi sposobami osiągana jest emocjonalność architektury i jej znaczenie w najnowszych teoriach zasad projektowania.

Osiągniecie celu jest zdeterminowane następującymi pytaniami badawczymi:

1. Czy i na jakim poziomie istnieje związek teorii generatywnych w projektowaniu architektury z procesami powstawania form życia w naturze?

2. Czy interdyscyplinarność i wielokryteriowość procesów projektowania tego typu architektury przyczynia się do unifikacji przestrzeni architektonicznej z środowiskiem i człowiekiem jako użytkownikiem przestrzeni?

3. Na ile pojęcie formy i jej emocjonalnego oddziaływania w przestrzeni jest narzeczem precyzyjnych, naukowych dociekań i analiz, porównań procesów, parametrów, ograniczeń, algorytmów, a więc kalkulacją obiektywnych uwarunkowań projektowanej architektury? Na ile emocjonalne i architektoniczne znaczenie architektury jest warunkowane decyzjami indywidualnymi projektanta?

4. W jaki sposób architektura osiąga pełnię formy przestrzennej poprzez programowaną psychologię, bezpieczeństwo, dostępność, technologię, ekologię, funkcję?

W celu odpowiedzi na to pytanie postawiono tezę: wielokryteriowość projektowania generatywnego, możliwości testowania i porównywania jednocześnie wielu relacji oraz zależności w danym założeniu projektowym, pragmatyzm w procesach projektowych generuje naukową argumentację, podstawę, matrycę projektu. System ograniczeń wynikających z pragmatyzmu i eliminacji wszelkich niedogodności w ramach wewnętrznych relacji poszczególnych parametrów wspomaga decyzyjność projektanta do przyjętego rozwiązania formalnego. Pomaga jednocześnie sprawniej i efektowniej uzyskiwać innowacyjność i wyraz samej formy architektonicznej. Jednym słowem : ograniczenie daje wolność. Systemy generatywne skupiające się na ścisłym selekcjonowaniu, wykluczaniu oraz ograniczeniach przyjętych kryteriów paradoksalnie pozwalają osiągać duże lepszą architekturę. Podejmowanie w takim wypadku decyzji projektowych jest łatwiejsze, gdyż dostarcza zakres informacji pragmatycznych i uargumentowanych naukowo. Teoria projektowania włączająca oraz akcentująca co ważniejsze kryteria i cele projektu jest gwarantem wysokiej jakości architektury. Ta jakość nie jest wynikiem poszukiwania piękna architektury, ale szerokim spectrum składowych projektu, którego wspólnym wyznacznikiem jest zrównoważona ekologicznie, bezpieczna i dostępna architektura. Wypadkową tych wszystkich jest ostatecznie forma. Proces tak artykułowanej architektury jest identyczny z procesami powstawania "formy" - życia w przyrodzie. Odkrywczość metod generatywnych w projektowaniu polega na odwołaniu się do reguł świata biologicznego i genetyki jako systemu proceduralnego w budowaniu życia i jego równowagi.

\section{Materiał badawczy}

W ostatniej dekadzie możemy wskazać wiele ważnych w historii architektury najnowszej obiektów zaprojektowanych zgodnie z zasadami projektowania generatywnego. Niektóre zespoły projektantów programowo 
specjalizują się tylko w takim podejściu do architektury. Z kanonów „wielkich" architektury generatywnej najnowszej możemy wskazać Normana Fostera, Coop Himmelblau, Herzog \& Meuron, UN studio i wielu, wielu innych. Obiekt powstały w Nowym Jorku zaprojektowany zgodnie z regułami generatywnymi jest dobrym w tym wypadku materiałem do analiz, porównań i wniosków w myśl postawionej wyżej tezy. Budynek zaprojektowany i realizowany w 2009 roku przez architektów spod szyldu Morphosis zmienił w dużej mierze krajobraz obszaru placu Cooper Square na Manhattanie. Operując terminologią generatywną - zmienił - osiągając lepszą jakość przestrzeni miejsca oraz integrując proces projektowania i sam budynek z pojęciami rozwoju zrównoważonego. Niewątpliwe i bezspornie obiekt jest oddźwiękiem myślenia wielokryteriowego w projektowaniu. Stąd w niniejszej dysertacji posłuży za materiał badawczy w celu lepszego rozumienia teorii generatywnej i jej zastosowania praktycznego.

\section{Metodyka}

Metodyka pracy odnosi się do empirycznego rozumienia działań teorii generatywnych w projektowaniu architektonicznym. Na poziomie opisu budynku 41 Cooper Union Square posłużono się analizą źródeł pisanych, głównie publikacji anglojęzycznych dostępnych w literaturze. Obiekt obecnie jest eksponowanym i szeroko opisywanym przykładem w ikonografii architektury najnowszej. Sam proces projektowy, bardzo transparentny i metodologicznie naukowy jest dostępny na stronach internetowych biura projektowego Morphosis, co w dużej mierze wspomogło pracę nad niniejszym artykułem. Materiał badawczy został więc opracowany poprzez analizę źródeł pisanych i ikonografię rysunkową oraz inwentaryzację fotograficzną projektu oraz realizacji.

Zakres przywoływanej teorii generatywnej w projektowaniu oparty jest na doświadczeniach empirycznych. Sama teoria systemów projektowania generatywnego jest metodyką projektowania i analizy. Na czym polega i co to jest?

Tłumaczenie oksfordzkiego słownika ${ }^{1}$ podaje następującą definicję terminu z angielskiego Generative Synthesis System:

- Generative: „... generowanie, zdolność reprodukcji i wariantowania...”

- System: „... zestaw danych elementów (modułów, algorytmów) współpracujących ze sobą w ramach całego mechanizmu..."

- Synthesis: „... kombinacja wzorów kompozycji; z uwzględnieniem wariantowości form, układów planów, systemów - synteza..."

W luźnym tłumaczeniu projektowanie generatywne określa mechanizmy zdolne do wytwarzania alternatywnych rozwiązań, gdzie dana problematyka projektu jest rozwiązywana poprzez szereg wariantów celem porównania, oceny, modyfikacji i ostatecznie selekcji do kolejnych etapów projektowania. Metodą projektowania staje się zdefiniowanie procedur określanych jako algorytmy w postaci parametrów i relacji. Relacje te składają się z trzech typów: zasad, powiązań i ograniczeń².

Zasady projektowania realizowane są przez:

- Konstrukcje kontrolujące zachowania „algorytmów”.

- Powiązania określające wewnętrzne relacje między algorytmami i parametrami.

- Ograniczenia mające kontrolować zachowanie algorytmów i parametrów.

Zasady wyznaczają myśl przewodnią i sposoby zbudowania algorytmów.

Powiązania określają wewnętrzne relacje między algorytmem i parametrami

Ograniczenia kontrolują zachowanie algorytmów i parametrów - decydują o porządku przestrzeni. ${ }^{3}$

2 Wojtkiewicz S. (2014) Generative Systems In architecture design. Generative Art 2014, XVII International Conference, Ed. by Celestiono Soddu, Enrica Calabella, Wydawnictwo Argona, Politechnika Mediolańska, Rzym, Włochy, str. 333-347 
W oparciu o takie założenia metodologiczne analizowana i opisana będzie tektonika architektoniczna budynku Cooper Union. Istotne wydaje się więc wskazanie w pierwszej części właściwości teorii generatywnych w projektowaniu, a następnie ukazanie ich w praktycznym zastosowaniu w projektowaniu architektonicznym. W tym wypadku posłuży ona do wskazania reguł wielokryterialnych obiektu architektonicznego z uwzględnieniem tez architektury bezpiecznej i dostępnej.

\section{O projektowaniu genertywnym w architekturze}

W trakcie poszukiwań projektowych celem uzyskania najlepszego rozwiązania zazwyczaj zakładamy kilka koncepcji architektonicznych opartych na wybranych założeniach geometrii, technologii, funkcji, kompozycji. Następnie porównujemy poszczególne warianty i wybieramy do dalszej pracy propozycję o największym potencjale. Wybór i porównanie jest możliwe wtedy, gdy mamy liczbę alternatyw do porównania i selekcji. Jeff Heiserman twierdzi, że "generative synthesis system" w projektowaniu oparty jest na wytwarzaniu wielu alternatyw do porównania i selekcji ${ }^{4}$. Traktując niniejsze stwierdzenie w kategoriach proceduralnych możemy zautomatyzować proces projektowania generując szereg alternatywnych koncepcji celem porównania, selekcji oraz sformułowania gramatyki języka projektowania.

Herbert Simon ${ }^{5}$ opisuje system generowania elementów projektu i metod jego sprawdzania w formie pętli co przedstawia diagram (Ryc. 1):

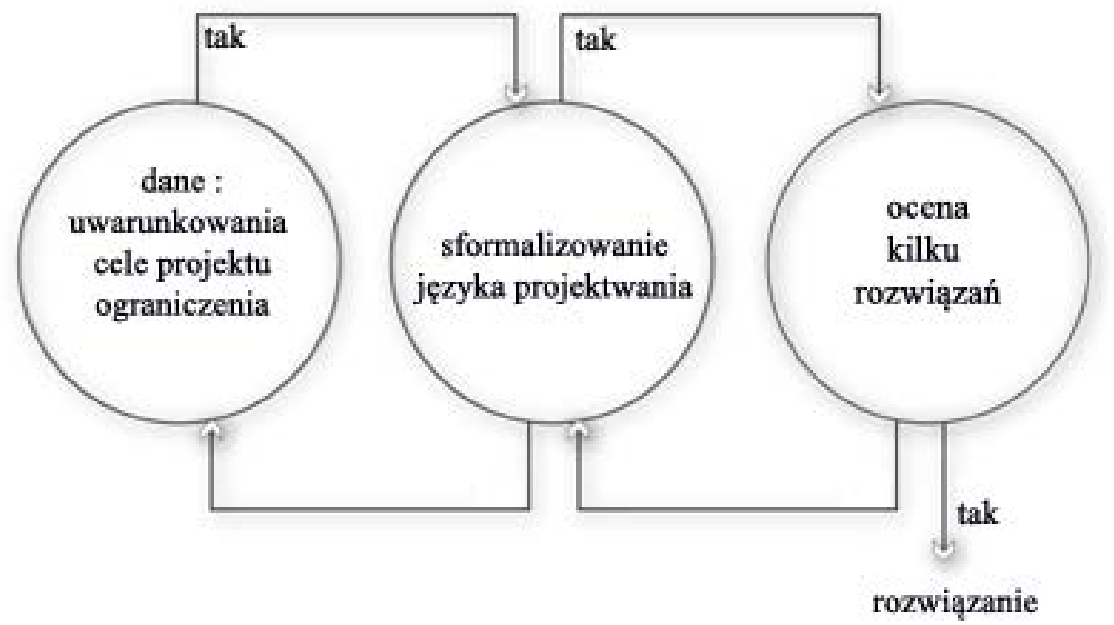

Ryc. 1. „Pętla projektowania" wg Herberta Simona, źródło: opracowanie własne

Twierdzi, że integracja systemu generowania i syntezy w procesie projektowania architektonicznego jest możliwa poprzez sformalizowanie jasnych definicji celów szczegółowych założeń projektowych. Proces ten odbywa się w postaci zestawu generatywnych instrukcji projektowych. Jest to rodzaj języka definiującego sens przyszłej architektury (Ryc. 2). Diagram poniżej ilustruje proces integracji procedur generatywnych w osiąganiu rozwiązania projektowego: 


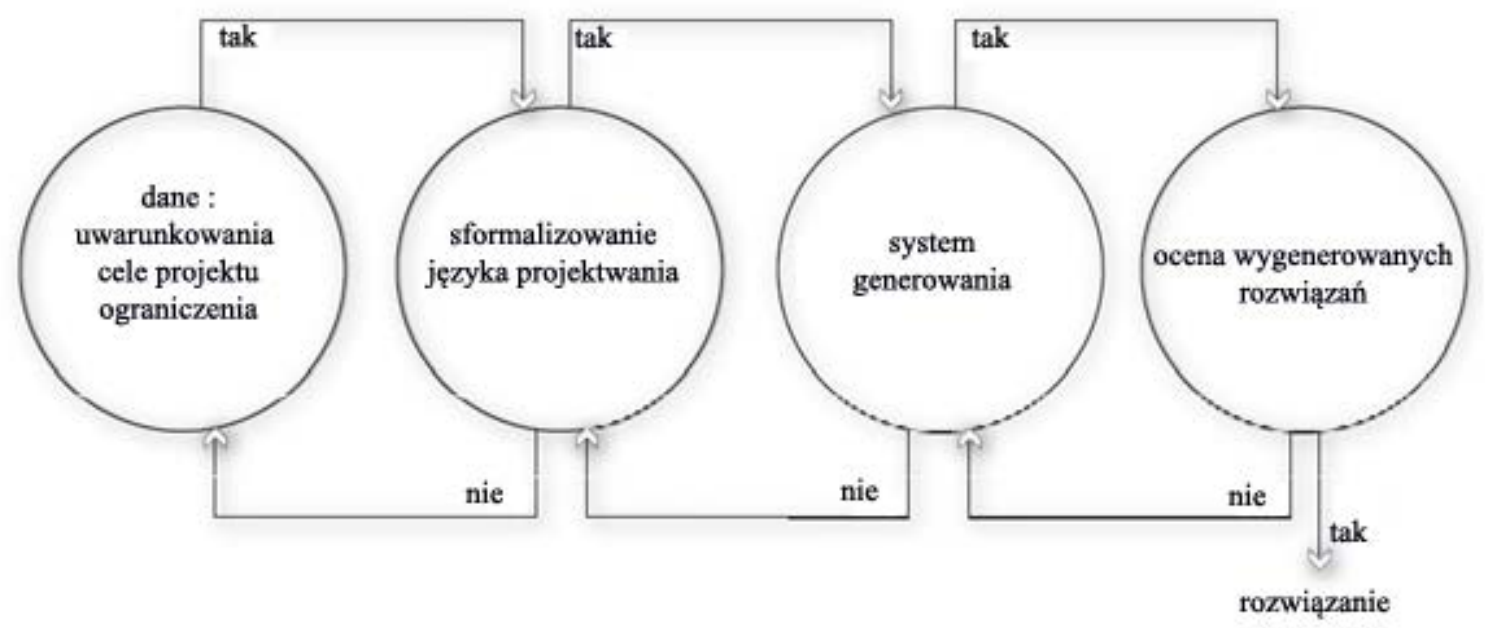

Ryc. 2. "Pętla projektowania” z uwzględnieniem zasad generatywnych, źródło: opracowanie własne

Procesy projektowania tworzy ścisła zależność poszczególnych danych wejściowych. Ta zależność wytwarza rodzaj pętli, który kooperuje ze sobą, wzajemnie się uzupełnia oraz porównuje generując dane wyjściowe do dalszych prac nad projektem. W sposób strukturalny powstają kolejne komponenty, które układają się w zależną, wynikową i jednorodną całość. Generowanych jest coraz więcej informacji, które wytwarzają parametry zachowań i dalsze procesy projektu.

Podobne zjawiska możemy zaobserwować w przyrodzie. W przyrodzie na poziomie molekularnym informacja genetyczna jest przenoszona przez wielkocząsteczkowe molekuły zwane DNA, który są kopiowane i dziedziczone w kolejnych pokoleniach ${ }^{6}$. Dane cechy są przekazywane jako instrukcje do budowy i eksploatacji organizmu. Instrukcje te, zasady zawarte w segmentach DNA zwane są genami. DNA składa się z sekwencji prostych jednostek jako instrukcji w kodzie genetycznym. Przypomina to sposób literowania wyrazów. Genotyp jako ta najważniejsza cząstka budulcowa jest genetycznym wkładem w specyfikę danego organizmu. Fenotypy są to zauważalne cechy lub atrybuty organizmu, takie jak jego morfologia, rozwój, zachowania, właściwości biochemiczne i fizjologiczne (Ryc. 3).

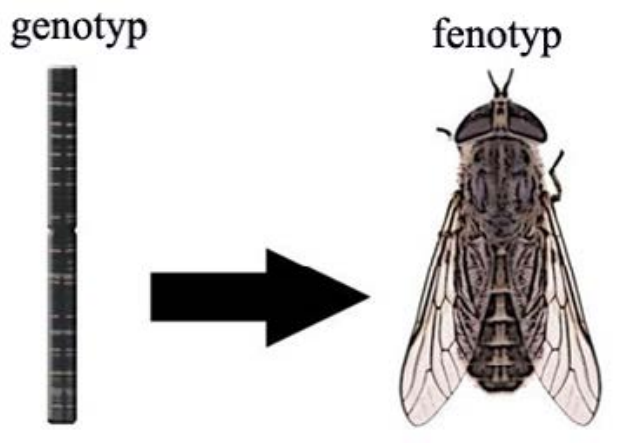

Ryc. 3. Genotyp jako kod tworzenia fenotypu - na przykładzie formy muchy, źródło: opracowanie własne

W projektowaniu architektonicznym, wyartykułowane zasady postępowania projektowego reprezentują biologiczny genotyp projektu, który zgodnie z metodami generatywnymi może być użyty do generowania poszczególnych fenotypów. W latach 70-tych autorzy Stiny i Mitchell ${ }^{7}$ w oparciu o twórczość Palladia opracowali zbiór zasad i gramatycznych składni (gramatyka kształtu - genotyp) twórczości włoskiego architekta (Ryc. 4). 
Gramatyka Kształtów jako system działań projektowych zapewniają automatyzacje i manipulację generowania formy zgodnie z narzuconymi przez projektanta instrukcjami. Badania w Gramatyce Kształtów koncentrują się na analizie istniejącego prototypu projektu i generowania z niego nowych wzorów. Związek z prawidłami w przyrodzie jest bardzo bliski wręcz identyczny.
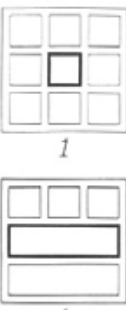

6

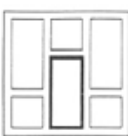

11

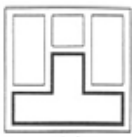

16

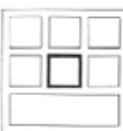

2
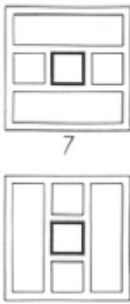

$$
12
$$

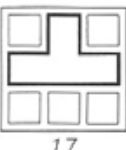

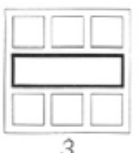

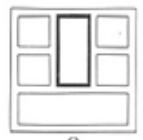

8

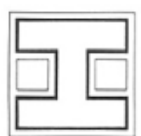

13.

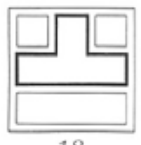

18
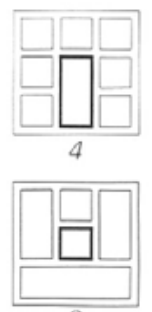

9

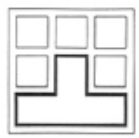

14

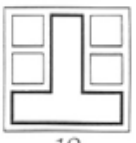

19
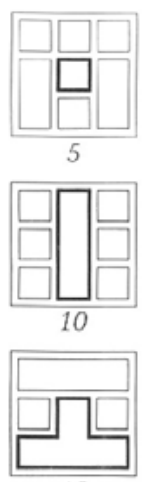

15

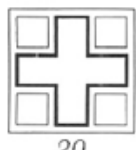

Ryc. 4. Gramatyka kształtów architektury Palladia, źródło: Stinny i Mitchell 1978

Koncepcja projektowania generatywnego nie jest teorią nową i szereg jej aplikacji możemy znaleźć w przykładach historycznych. W gruncie rzeczy jest to teoria świadomości projektowego, proceduralnego postępowania. Przykłady zastosowania takich systemów w projektowaniu możemy wskazać w twórczości Salivana, Eisenmmana, Alexandra, Palladia i wielu, naprawdę wielu innych projektantach.

Opisując procesy projektowania w duchu algorytmicznym - genotypicznym, przykłady możemy wskazać w wielu realizacjach współczesnych. (Ryc. 5, 6)
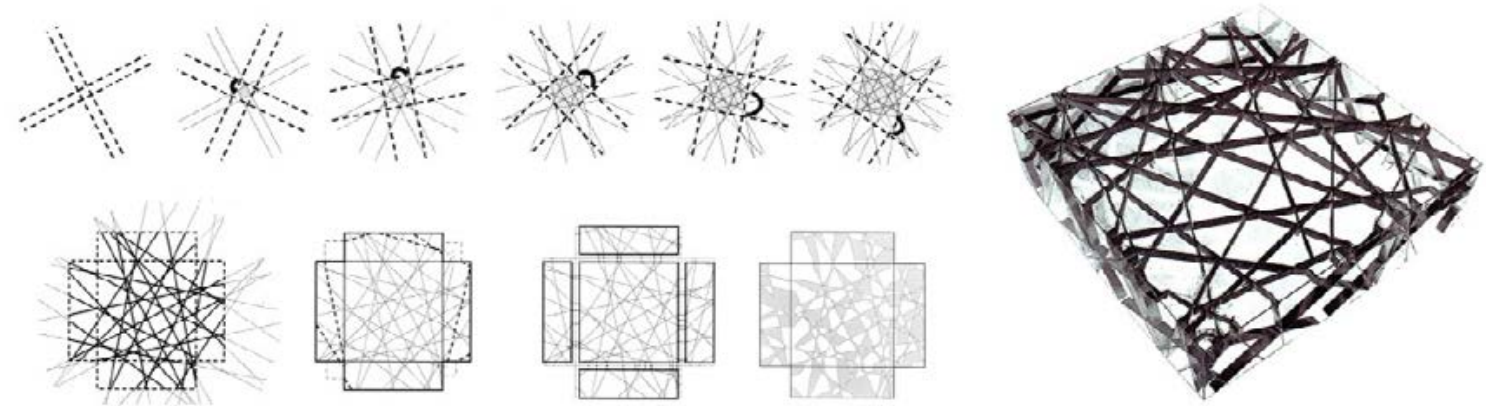

Ryc. 5. Cecil Balmond i Toyo Itto opracowali algorytm (genotyp), który określa formę (fenotyp) Serpentine Pavilion, źródło: opracowanie własne na podstawie projektu 

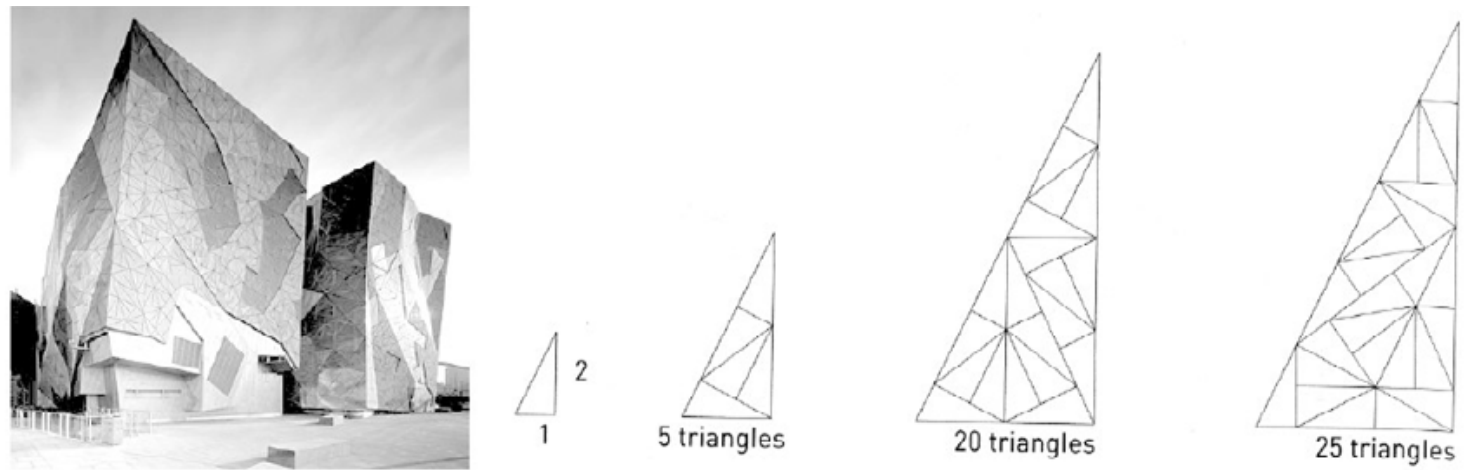

Ryc. 6. Lab-Architecture użyli algorytmu fraktalu aby zaprojektować formę elewacji Federation Square w Melbern, źródło: opracowanie własne na podstawie projektu.

Myślenie o procesach projektowania jako sposobie poszukiwania, tudzież artykułowania algorytmu i jego eksploracji w kierunku fenotypu staje się kluczowe w rozumieniu tego współczesnego kierunku w projektowaniu. Odniesienia do reguł przyrody wydają się pomocne w rozumieniu znaczeń tego typu architektury. Kolejnym krokiem w preformacji generatywnego procesu projektowania są systemy analizy. I w tym wypadku podstaw definicji można dopatrywać się w regułach świata przyrody i biologii. Wspomniany fenotyp pojedynczego organizmu zależy od środowiska, w którym mieszka. Zmiana środowiska może mieć również wpływ na jego właściwości. Uwarunkowania i zmiany środowiska decydują o ewolucji żyjących w nich organizmów. Dobór naturalny odbywa się przez wiele pokoleń danego gatunku, w których to drogą selekcji kształtowane są cechy organizmów dające im przewagę i korzyści względem danego środowiska. Jednocześnie eliminowane są w następnych pokoleniach cechy, mniej korzystne z punktu dostosowania się do środowiska. Naturalna selekcja zależy od możliwości ewolucyjnych organizmu względem zmian w środowisku i samych procesów życiowych. Uwarunkowania organizmu są mierzone przez zdolność do przetrwania i reprodukcji, która określa wielkość swojego wkładu genetycznego do następnego pokolenia ${ }^{8}$. Przyroda stworzyła zatem system analizy i testowania genotypów celem ulepszania i ciągłej ewolucji nieustannie kreowanej „formy” - życia (Ryc. 7).
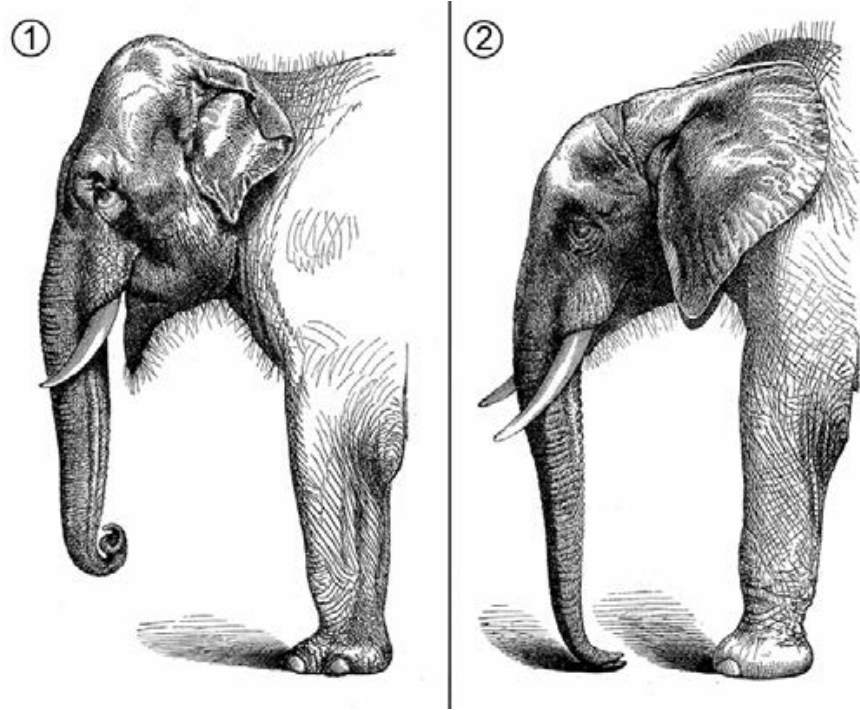

Ryc. 7. Porównanie słonia afrykańskiego z indyjskim. Inne uwarunkowania środowiskowe decydują o odmiennej ewolucji fenotypu gtunku, źródło: opracowanie własne 
Odnosząc systemy analizy w projektowaniu generatywnym wskazać należy zależności, które wpływają na projekt architektoniczny. Zależności te określają składniki quantative i qualitative projektu. Wartości quantitative mają wpływ na następujące warunki projektu architektury:

- uwarunkowania ekonomiczne (koszty budowy, użytkowania, budżet, zyski, straty inwestycji),

- uwarunkowania środowiskowe i fizyczne (systemy doświetlenia, nasłonecznienia, aspekty termalne, akustyka, mikroklimat),

- ergonomia i dostosowanie użytkownikom, osobom niepełnosprawnym

- konstrukcja

Wartości qualittive mają wpływ na odbiór przestrzenny formy i jej kontekst. Odnoszą się do aspektów humanistycznych architektury i estetyki.

System generowania oraz analizy umieszczony w jednej pętli testuje się nawzajem przyczyniając do wytwarzania systemu reguł, celów architektury, algorytmu, czyli genotypu formy, parametrów architektury i jej ograniczeń. W ten sposób następuje proces powstawania projektu architektonicznego. Zespół reguł przy jednoczesnych systemach modularnych w postaci algorytmu, parametrów i ograniczeń pozwala ewoluować formą oceniając poszczególne prototypu w systemie analizy (Ryc. 8). Układ symbiotyczny decyduje o przestrzeni architektury dostępnej, bezpiecznej, metodologicznie pewnej bo opartej nie na intuicji, ale na pragmatyce i dedukcji. Takie też cechy posiada budynek Cooper Union w Nowym Jorku.

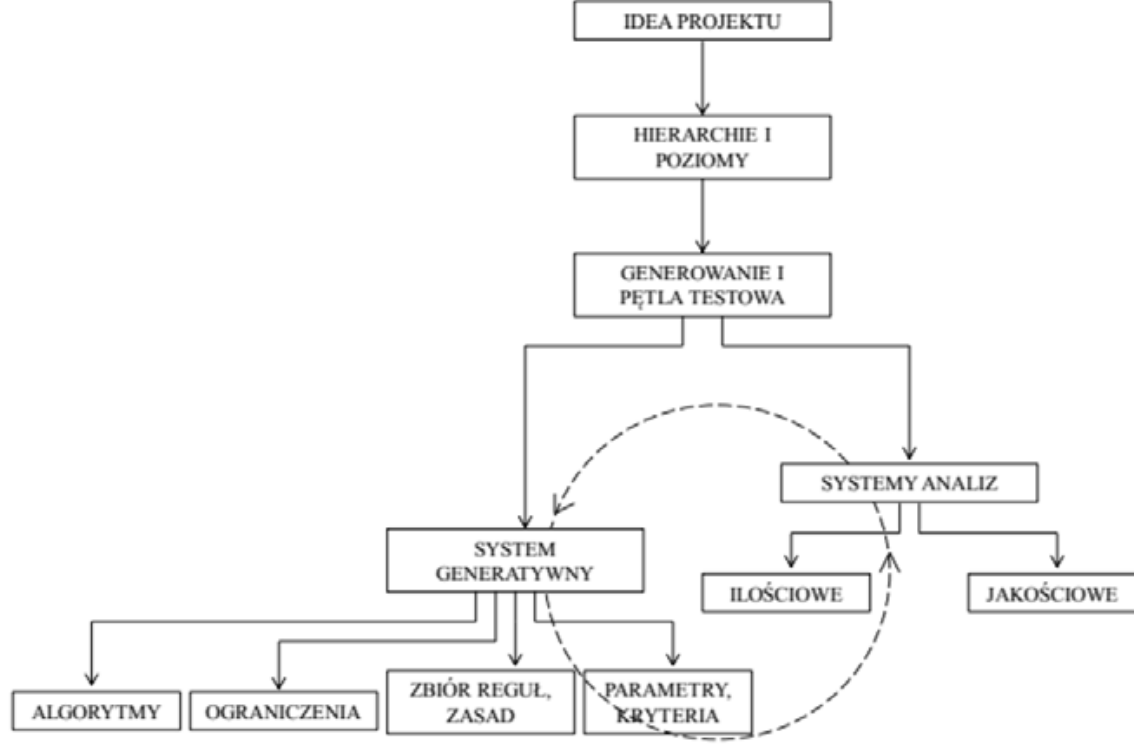

Ryc. 8. Schemat działania projektowania generatywnego w architekturze, źródło: opracowanie własne na podstawie projektu.

\section{Cooper Union Square}

Opisywany obiekt powstał podług reguł generatywnego projektowania systemowego, zintegrowanego. Budynek 41 Cooper Square należący do kampusu Cooper Union na Manhattanie w Nowym Jorku został zaprojektowany przez pracownię architektury Morphosis, której założycielem jest laureat nagrody Pritzkera architekt Thom Mayn. Dziewięciopiętrowy budynek o pwierzchni $16300 \mathrm{~m}^{2}$ (szerokość $30 \mathrm{~m}$, długość $50 \mathrm{~m}$, wysokość $41 \mathrm{~m}$ ) mieści się między placem Cooper Square, a ulicami $6^{\text {th }}$ Street i East 7 Street (Ryc. 13) ${ }^{9}$. Budynek pełni funkcję ośrodka akademickiego, w którym mieści się Albert Nerken School of Engineering z dodatkowymi fakultetami nauk humanistycznych, sztuki oraz architektury. Dodatkowo w obiekcie znajduje się galeria wystawowa, audytorium oraz powierzchnia handlowa w parterze. Budynek powstał w miejscu dwupiętrowego z 1912 roku Ab- 
ram S. Hewitt Memorial Building o funkcji szkoły artystycznej. Jego rozbiórka była częścią planu rozbudowy tejże szkoły w ramach wspomnianego kampusu dydaktycznego Cooper Union. Po szeregu perturbacjach prawnych i społecznych budowa została rozpoczęta w 2006 roku i ukończona w 2009. Nowy budynek akademicki dla The Cooper Union aspiruje do promowania postaci filantropa i nauczyciela Petera Coopera oraz 150-letniej tradycji instytucji akademickiej. Niewątpliwą aspiracją jest też charakter centrum, jako nowoczesnych i innowacyjnych rozwiązań w sztuce, architekturze i inżynierii. ${ }^{10}$

Forma budynku jest transparentna i posiada ogólnodostępne przestrzenie publiczne łącząc się fizycznie, społecznie i kulturowo z miejską tkanką. Reguła "double skin" nadaje charakteru i decyduje o wymowie przestrzennej obiektu. Półprzezroczyste warstwy perforowanej stali szlachetnej pokrywają elewację zapewniając kontrolę dostępu światła i wentylację. Ten zabieg zapewnia do 50\% zmniejszenia zużycia ciepła. Ocena strat energetycznych budynku wpływała też na wzmacnianie jego narożników innym rodzajem preferowanej blachy, zapewniając zatrzymanie ciepła w najbardziej krytycznych miejscach.

Dodatkowa ekspresja bryły jest podkreślona pęknięciami i rzeźbiarskim modelunkiem w przestrzeni. W tym miejscu znajduje się wejście - to kolejna reguła w wypracowywanym generatywnie zestawie założeń strategicznych formy. Forma obszernego atrium, która identyfikuje wnętrze jest także zaznaczona opisanym pęknięciem części zewnętrznej. Korelacja funkcji i formy jest widoczna. Procesy geometrycznych - algorytmicznych relacji obrazuje ilustracja (Ryc. 9).
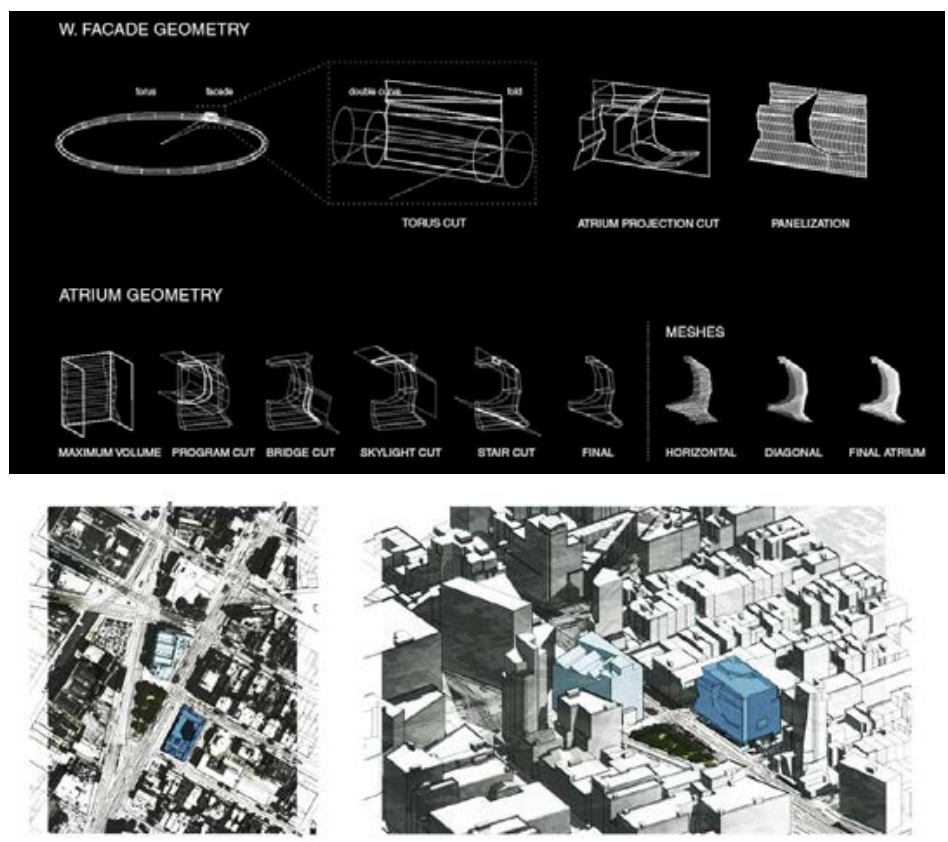

Ryc. 9. Generowanie geometrii atrium i elewacji frontowej budynku Cooper Union. Lokalizacja budynku w przestrzeni miasta, źródło: materiały Morphosis Architects.

Jest to wybitny przykład osiągania przestrzeni projektowej według przyjętych kryteriów wzajemnych relacji i parametryzacji oraz transformacji w osiągnięciu efektu końcowego. Układ funkcjonalny, zwłaszcza strefy publicznej ma za zadanie promować współpracę i interdyscyplinarność trzech szkół artystycznych. Pionowa strefa owalnego atrium stała się miejscem towarzyskich, nieformalnych spotkań i wykładów. Jej statut jest łatwo rozpoznawalny. Z wejściowego holu można zauważyć dominujące schody o szerokości ok. 6,1 m wznoszące się przez cztery kondygnacje i prowadzące do podwójnie wysokiego, przeszklonego, studenckiego salonu z widokiem na miasto. Od piątej do dziewiątej kondygnacji znajdują się hole oraz miejsca spotkań. Budynek jest strefowany. Przestrzeń biurowa zajmuje około $1020 \mathrm{~m}^{2}$, sale dydakcyjne $-1430 \mathrm{~m}^{2}$, laboratoria $-3623 \mathrm{~m}^{2}$, pracownie artystyczne - $929 \mathrm{~m}^{2}$, przestrzenie wspólne, publiczne - $929 \mathrm{~m}^{2}$ (Ryc. 10) ${ }^{11}$. Atrium stanowi pionową cyrkulację przestrzeni wnętrza oraz centrum prowadzące do znajdujących się wzdłuż korytarzy funkcji dydaktycznych. 

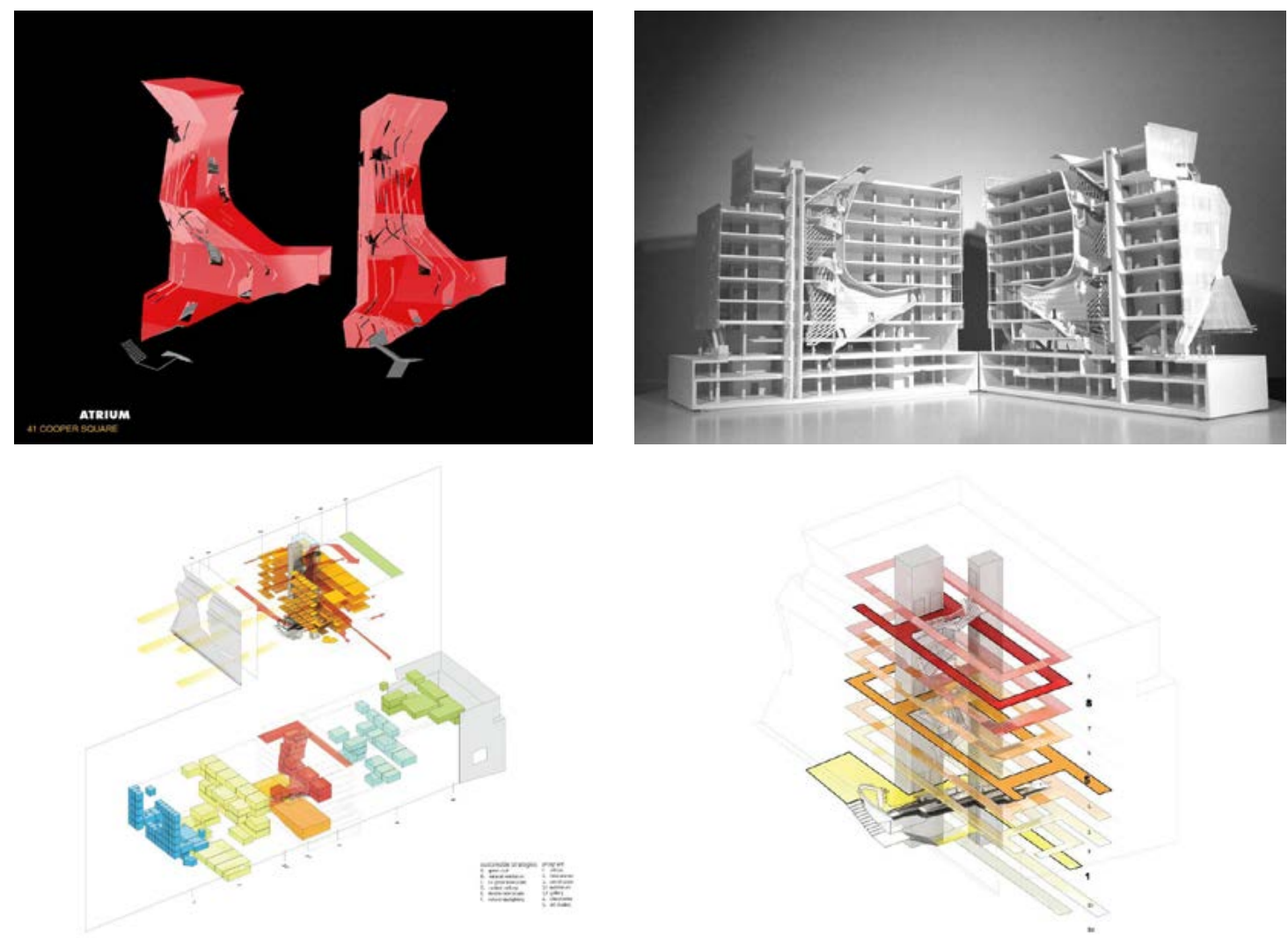

Ryc. 10. Układ funkcjonalny budynku Cooper Union, źródło: materiały Morphosis Architects.

Potwierdzeniem korzyści optymalizacji budynku jest nadany certyfikat LEED. System LEED (z ang. Leadership in Energy and Einvorenmental Design) został stworzony w 1998 roku przez niezależną amerykańską organizację Green Building Council, której celem jest propagowanie idei ekologii i zrównoważenia w budownictwie. To prestiżowe wyróżnienie potwierdza słuszność przyjętych kryteriów strategii projektowania obiektu. Wskaźniki budynku wręcz były optymalizowane w kierunku otrzymania jak najlepszych parametrów. Kryteria wariantowania i optymalizacji towarzyszą każdej towarzyszącej tu przestrzeni. Takim rozwiązaniem są promieniujące panele ( $z$ ang. Radiant Ceiling Panels). Ciepła i zimna woda przebiega przez panele sufitowe kontrolując temperaturę w budynku. Promieniujące panele pozwalają także 41 Cooper Square zaoszczędzić przestrzeń w budynku. Systemy gromadzenia wody oraz jej gospodarki na zielonych dachach zmniejszają zapotrzebowanie na wodę oraz jej odpływ do sieci kanalizacyjnej. Dzięki atrium oraz elewacjom światło dzienne w budynku jest dostarczane w sposób naturalny co zmniejsza także zapotrzebowania na energię elektryczną.

Celując w bezpieczeństwo i dostępność architektury w obiekcie zastosowano zasadę "the skip-stop stars". Zasada ma pobudzić aktywność fizyczną użytkownika obiektu. Polega ona na tym, że winda zatrzymuje się co trzecie piętro. Użytkownicy, którzy chcą dostać się na wyższe lub niższe piętro muszą pokonać odległość schodami. Z jednej strony zabieg ten wymusza aktywność fizyczną człowieka, z drugiej wiąże się z oszczędnościami energii elektrycznej. W budynku główne windy zatrzymują się na pierwszym, piątym i ósmym piętrze. Na każdej kondygnacji zatrzymują się windy drugorzędne służące do zadań takich jak przewożenie materiałów, dostaw, obsługi osób niepełnosprawnych. Większa część budynku została wykonana z materiałów odnawialnych, a udział materiałów wtórnych wynosi 15\%. Idea hig-tech i dekonstrukcji uwypukla zasadę projektowania od zewnątrz do środka. Tym samym elementy zewnętrzne odgrywają istotną rolę w kreacji wnętrza, a wnętrze poddane transparentności struktury elewacji przenosi swoje istnienie w strukturze ulicy.

Projektowanie od zewnątrz do środka, tak samo jak od środka do zewnątrz tworzy pewne napięcie, które pomaga tworzyć architekturę. Ponieważ to, co wewnątrz różni się od tego co na zewnątrz, ściana- miejsce zmiany- staje się wydarzeniem architektonicznym. Architektura powstaje w miejscu spotkania wewnętrznych 
i zewnętrznych sił funkcji i przestrzeni ${ }^{12}$. Budynek Cooper Union wyznaje zasadę jedności formy architektonicznej. Formalnie jest zbudowany z detalu osadzonego na ściśle opracowanej strukturze formy bryły. W przestrzeni miasta w ujęciu urbanistyki pełni także rolę dominanty. Regularność amerykańskiego historyzmu dzielnicy, w której wybudowano ten obiekt daje należne tło budynkowi wykonanemu ze stali i szkła. Tym samym Cooper Union poprzez detal, płaszczyznę i ścianę staje się ikoną. Trwałość statutu ikony w mieście, utwierdza zastosowana technologia i metodologia projektowania. Drugie ogniwo stanowi sens i myśl zastosowanej technologii. Opisana forma przestrzenna jest jedną z wielu, w których sens znaczenia i odbioru przestrzeni wpłynął na to, że stała się momentem refleksji. Patrząc na Cooper Union obiekt wyrosły w bardzo specyficznym kulturowo środowisku amerykańskim nie widzimy tła, kontekstu, nie widzimy też detalu. Głębsza refleksja dowodzi jednak, że miejsce zaczyna opisywać ów budynek, że metoda generatywnego projektowania tworzy sam sobie formę na temat rozwiązywania problemów dotyczących trwałości, celowości, dostępności, bezpieczeństwa i ekspresji. W tych działaniach rola metody projektowania określa zakres wymagań pragmatycznych ukrytych w sferze konstrukcji i użyteczności. W tej materii budynek Cooper Union (Ryc. 11) jak i doktryna projektowa realizowana w innych pracach grupy Morphosis jest spełnieniem ów postulatu.

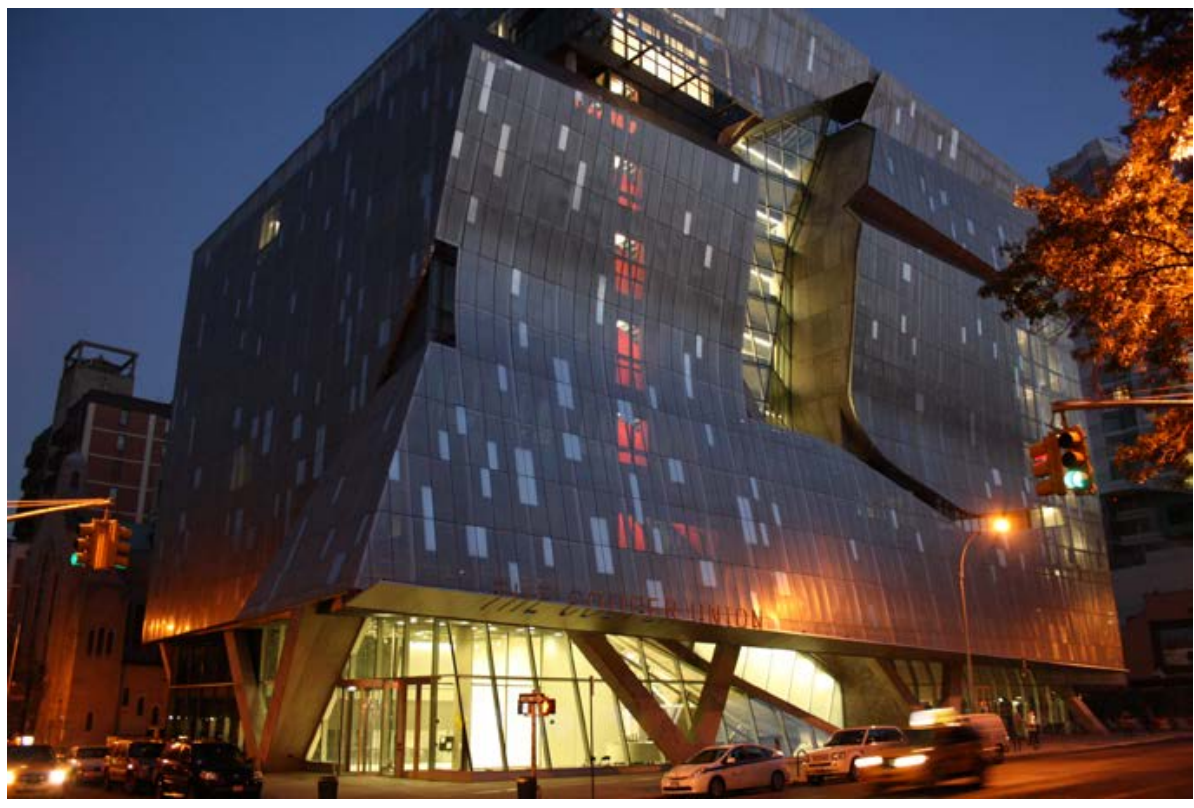

Ryc. 11. Budynek Cooper Union w perspektywie ulic Nowego Jorku, źródło: S. Wojtkiewicz.

\section{Wnioski}

Budynek 41 Cooper Square jest przykładem współczesnej myśli w osiąganiu statusu znaczącej architektury poprzez przyjęte procedury projektowania. Te reguły to myślenie o generatywnym procesie, który na etapie projektowania wytwarza bardzo zracjonalizowany układ parametrów, relacji, ograniczeń. W oparciu o algorytm powstaje forma architektury, która jest badana w poprzek przyjętych kryteriów quantative i qualitative. Osiągane rozwiązanie przestrzenne jest pochodną procesu, dlatego też architektura osiąga statut wartości empirycznej i wynikowej. Projektowanie generatywne jest skomplikowanym procesem, ale jej spełnienie decyduje o powstaniu architektury wybitnej, a nade wszystko wynikającej z uwarunkowań miejsca i środowiska, w którym powstaje. Projektowanie takie zbliżone jest do prawideł przyrody, dlatego jej znaczenie jest wielowątkowe, a oddźwięk wykracza poza przyjęte ramy definicji architektury i znaczeń czysto formalnych. 
Uogólniając:

- Systemy projektowania generatywnego pozwalają bardzo precyzyjnie realizować cele projektowe, gdyż poparte są empirycznym myśleniem o przestrzeni z uwzględnieniem wszelkich składowych projektu na poziomie poszczególnych relacji. Warianty rozwiązań wzajemnie się testują wykluczając potencjalne pomyłki.

- Architekt dobiera parametry generowania rozwiązań projektowych w zależności od funkcji budynku, tym samym zakładając priorytety bezpiecznej architektury i dostosowania architektury np. ludziom niepełnosprawnym można uzyskać bardzo zaawansowane pod kątem dostępności i bezpieczeństwa rozwiązania.

- Rozwiązania uwzględniające wielokryterialność projektu powinny przyczynić się do trwałości budynku i zwiększania jego wartości.

- System projektowania, generatywnego we wczesnych fazach koncepcyjnych projektu precyzują finalne rozwiązania.

- Dają lepsze rozumienie miejsca projektu i prognozują skutki poszczególnych decyzji projektowych.

- Możliwości modelowania komputerowego pozwalają w fazie projektu na symulację poszczególnych miejsc problematycznych rozwiązując je już w fazie konceptualnej.

- Korzystanie z zaawansowanych narzędzi analizy projektu daje bardziej niezawodne rozwiązania.

\title{
Literatura
}

[1] Heisserman J., Callahan S., Mattikalli R., (2000) A design representation to suport automatem design generation". In: Gero J. (ed).Artifical Intelligence In Design.

[2] Morphosis Architects (2009) "The Cooper Union" for the Advancement of Science and Art, ArchDaily, tłumaczenie własne.

[3] Norberg-Schultz Ch.,(2000) Bycie, przestrzeń i architektura, Warszawa

[4] Oxford Dictionaries. www.oxforddictionaries.com/oed

[5] Privault D., (2010) Ziemia Rośliny Zwierzęta, Larousse, wyd.polskie - Instytut Wydawniczy

[6] Simon H. (1991) The architecture of complexity. MIT Press Cambridge, Campbridge

[7] Stiny G., Mitchell W.J., (1978) The Palladian Grammar". Environment and Planning, volume 5.Cambridge, England

[8] Wojtkiewicz S. (2014) Generative Systems In architecture design. Generative Art 2014, XVII International Conference, Ed. by Celestiono Soddu, Enrica Calabella, Wydawnictwo Argona, Politechnika Mediolańska, Rzym, Włochy

\section{Cooper Union Square - save architecture, generative architecture}

\begin{abstract}
One of the design criteria of generative design systems is multivariants, including all components of the design process. Another key factor to consider is the safety and human-friendly environment of space. Generative systems are advanced language development of solid geometry of the building, its functions and sustainable system of investigation into spatial solutions, in which a person is treated as a priority. Cooper Union building designed by Morphosis group, located in New York, is an outstanding example of achieving interesting form of spatial and functional system. The procedures generative design stage helped largely shape the space available, but in many cases supporting the physical condition of man.

The article presents the scientific basis of the theory of generative used in the design of The Cooper Union Building for a sustainable environment and the architecture of intelligent not only in terms of aesthetic and functional, but the technology relating directly to the health of human attitudes - recipient designed space.
\end{abstract}

Keywords: generative design systems, architecture 